\title{
PENGARUH LOCUS OF CONTROL, KOMITMEN PROFESI, BUDAYA ORGANISASI, KEPUASAN KERJA, SISTEM KOMPENSASI SERTA SIKAP INDEPENDENSI TERHADAP PERILAKU AUDITOR DALAM MENGHADAPI KONFLIK AUDIT \\ Studi pada Auditor yang Bekerja di KAP Daerah Istimewa Yogyakarta dan Surakarta
}

\author{
Mei Dewi Meliana \\ Arif Sapta Yuniarto
}

\begin{abstract}
ABSTRACK
This research aims to determine effect of locus of control, profession commitment, organization cultural, job satisfaction, compensation system and independence attitude for auditor behavior in face on audit conflict. The analysis based on the answer of respondents who available through of questionnaire that distribute by Yogyakarta and Surakarta Public Accountant Office. Population from the auditor research who work in the Public Accountant Office were in Yogyakarta and Surakarta. The research using the purposive sampling method. Sample taken from auditor who minimal has worked during 2 years. Cronbach Alpha used to test reliability data and testdata isused kolmogorov_Smirnovnormality. Hypothesis tested by multiple regression. Result from the research revealed that there are locus of control effect, profession commitment, organization cultural, job satisfaction, compensation system, independence attitude for auditor behavior in face on audit conflict.
\end{abstract}

Keyword: Locus of control, profession commitment, organization cultural, job satisfaction, compensation system, independence attitude.

\section{PENDAHULUAN}

Perkembangan dunia yang semakin pesat mengakibatkan persaingan antara perusahaan semakin meningkat, serta permasalahan yang dihadapi semakin kompleks. Adanya hal tersebut membuat informasi akuntansi sangat dibutuhkan, khususnya akuntan publik. Akuntansi merupakan bidang yang sangat penting dalam suatu perusahaan. Jasa akuntansi dalam menyediakan informasi akuntansi perlu menjalin kerjasama dengan pihak manajemen dan publik untuk meningkatkan transparasi laporan keuangan. 
Selain keberhasilan dan kinerja seseorang dalam suatu bidang pekerjaan sangat ditentukan profesionalisme terhadap bidang yang ditekuninya. Profesionalisme sendiri harus ditunjang dengan komitmen seseorang terhadap organisasinya. Komitmen merupakan suatu konsistensi dari wujud keterikatan seseorang terhadap suatu hal. Adanya suatu komitmen dapat menjadi suatu dorongan bagi seseorang untuk bekerja lebih baik.

Profesi akuntan publik bisa dikatakan merupakan salah satu profesi kunci di era globalisasi untuk mewujudkan era transparasi bisnis yang fair. Oleh karena itu, kesiapan yang menyangkut profesionalisme mutlak diperlukan. Profesionalisme mensyaratkan tiga hal utama yang harus dipunyai oleh setiap anggota profesi, yaitu keahlian, pengetahuan, dan karakter (Dwintasari, 2008). Auditor mempunyai standar yang seharusnya bisa mencegah terjadinya kegagalan audit. Yang menyatakan bahwa auditor tidak dibenarkan memihak kepada kepentingan siapapun, sebab jika tidak dia akan kehilangan sikap independensi yang sangat penting untuk mempertahankan kebebasan berpendapatnya.

\section{TINJAUAN PUSTAKA DAN PENGEMBANGAN HIPOTESIS}

\section{Locus Of Control}

Pevin dalam Ayudiati (2010) dalam Waris (2012) menyatakan bahwa locus of control adalah istilah dalam psikologi yang mengacu kepada keyakinan seseorang tentang apa yang menyebabkan hasil yang baik atau buruk dalam hidupnya. Lefcourt (1982) dikutip dalam Prastiwi (2011) menyatakan bahwa internal locus of control ditunjukan dengan pandangan bahwa peristiwa baik atau buruk yang terjadi diakibatkan oleh tindakan seseorang. Sementara external locus of control ditujukan dengan pandangan bahwa peristiwa baik atau buruk yang terjadi tidak berhubungan dengan perilaku seseorang pada situasi tertentu, oleh karena itu disebut dengan di luar kontrol seseorang. 


\section{Komitmen Profesi}

Larkin (1990) dalam Suhakim dan Arisudhana (2012) menyatakan komitmen profesional adalah tingkat loyalitas individu pada profesinya seperti yang dipersepsikan oleh individu tersebut. Menurut Edelmann (1997: 103) dalam Prastiwi (2011) komitmen profesi adalah tingkat loyalitas individu terhadap organisasi dalam melaksanakan tugas dan menaati norma aturan dan kode etik profesi. Bagi seorang auditor komitmen profesi sangatlah diperlukan, karena berkaitan dengan loyalitas individu dalam melaksanakan tugas dan profesinya sebagai akuntan publik.

\section{Budaya Organisasi}

Budaya organisasi adalah seperangkat perilaku, perasaan dan seperangkat psikologis yang terinternalisasi sangat mendalam dan dimiliki bersama oleh anggota organisasi. Gibson, et al. (2002) dalam Trisnaningsih (2007) mendefinisikan budaya organisasi sebagai suatu sistem nilai-nilai, keyakinan dan norma-norma yang unik, dimiliki bersama oleh anggota suatu organisasi. Budaya organisasi dapat menjadi kekuatan positif dalam mencapai prestasi organisasi.

\section{Kepuasan Kerja}

Kepuasan kerja (join satisfaction) adalah sebagai suatu perasaan positif tentang pekerjaan seseorang yang merupakan hasil dari sebuah evaluasi karakteristiknya. Seseorang dengan tingkat kepuasan kerja yang tinggi memiliki perasaan-perasaan positif tentang pekerjaan tersebut, sementara seseorang yang tidak puas memiliki perasaan-perasaan yang negatif tentang pekerjaan tersebut (Robbins \& Judge, 2008: 99).

\section{Sistem Kompensasi}

Kompensasi adalah segala sesuatu yang diterima para karyawan sebagai balas jasa untuk kerja mereka. Kompensasi merupakan fungsi manajemen personalia yang paling sulit dan membingungkan. Tidak hanya karena pemberian kompensasi 
merupakan salah satu tugas yang paling kompleks, tetapi juga salah satu aspek yang paling berarti baik karyawan maupun organisasi (Handoko, 2010). Kompensasi penting bagi karyawan sebagai individu karena besarnya kompensasi mencerminkan ukuran nilai karya mereka diantara para karyawan itu sendiri, keluarga dan masyarakatnya.

\section{Sikap Independensi}

Menurut Mulyadi (2002: 26), independensi adalah sikap mental yang bebas dari pengaruh, tidak dikendalikan oleh pihak lain, tidak tergantung pada orang lain. Independensi juga berarti adanya kejujuran dalam diri auditor dalam mempertimbangkan fakta dan adanya pertimbangan yang objektif tidak memihak dalam diri auditor dalam merumuskan dan menyatakan pendapatnya. Sedangkan menurut Arens dan Loebbecke (1995) dalam Kasidi (2007) mendefinisikan independensi dalam auditing berarti berpegang pada pandangan yang tidak memihak di dalam penyelenggaraan pengujian audit, evaluasi hasil pemeriksaan, dan penyusunan laporan audit.

\section{Perilaku Audit}

Menurut Robbins dan Jugde (2008: 92), perilaku merupakan komponen sikap. Sikap (attitude) adalah pernyataan evaluatif, baik yang menyenangkan maupun yang tidak menyenangkan, terhadap objek, individu, atau peristiwa. Tiga komponen dalam sikap adalah kesadaran, perasaan dan perilaku. Menurut VIE theory dalam Ahim Abdurahim dan Nur Indriantoro (2000: 1) dalam Suhakim dan Arisudhana (2012), perilaku merupakan hasil tindakan dalam memilih berbagai alternatif yang bertujuan untuk memaksimalkan kenikmatan (pleasure) dan menghindari penderitaan (pain).

\section{Konflik Audit}

Menurut Robbins \& Judge (2008) konflik sebagai sebuah proses yang dimulai ketika suatu pihak memiliki persepsi bahwa pihak lain telah memengaruhi secara 
negatif, atau akan memengaruhi secara negatif, sesuatu yang akan menjadi perhatian dan kepentingan pihak pertama. Sedangkan Watkins (1995) dalam Prastiwi (2011) memiliki pandangan berbeda. bahwa konflik tidak dapat dihindari karena konflik akan ada rasa tidak memerlukan perubahan dan perhatian tidak akan tertuju pada masalah. Secara umum kita dapat mendefinisikan konflik dalam batasan pengaruhnya dalam organisasi.

\section{Pengaruh Locus of Control terhadap Perilaku Auditor dalam Menghadapi Konflik Audit.}

Wolfe dan snoek (1962) dalam Prastiwi (2011) menyatakan bahwa konflik peran timbul karena adanya dua perintah yang berbeda yang diterima secara bersamaan. Pelaksanaan satu perintah saja akan mengakibatkan terabaikannya perintah yang lain. Perintah pertama datangnya dari kode etik profesi, sedangkan perintah kedua datang dari sistem yang berlaku di kantor. Semakin tinggi locus of control internal karyawan, maka akan meningkatkan kepuasan kerja karyawan. Dari locus of control kita dapat melihat perilaku auditor dalam pengambilan keputusan ketika menghadapi situasi konflik apakah auditor mendapat pengaruh dari intern atau ekstern. Setelah mengetahui, auditor dapat mengantisipasi agar dapat mengendalikan diri dari berbagai masalah serta tidak ada salah saji dalam laporan hasil audit.

Penelitian Kurnia (2002) dan Abdulloh (2006) telah membuktikan adanya pengaruh signifikan atas variabel locus of control terhadap kepuasan kerja. Berdasar pemaparan teori dan penelitian terdahulu maka dirumuskan hipotesis sebagai berikut:

$\mathrm{H}_{1}$ : locus of control berpengaruh terhadap perilaku auditor dalam menghadapi konflik audit. 
Pengaruh Komitmen Profesi terhadap Perilaku Auditor dalam Menghadapi Konflik Audit.

Seorang audit dapat dikatakan mempunyai tingkat loyalitas tinggi ketika melaksanakan aturan terlihat dalam komitmen profesinya. Dengan komitmen profesi yang rendah, seorang auditor akan sulit dalam memperoleh kepercayaan diri klien maupun rekan kerja yang akhirnya dapat berdampak pada hilangnya profesi sebagai auditor Prastiwi (2011).

Penelitian Herawati (2007) telah membuktikan adanya pengaruh yang signifikan atas variabel persepsi profesi dan kesadaran etis terhadap komitmen profesi. Semakin tinggi persepsi profesi yang di miliki oleh seorang auditor akan berakibat pada peningkatan pemahaman terhadap profesi yang digelutinya sehingga akan berdampak pula pada peningkatan komitmen profesi yang membuat terciptanya profesionalisme yang tinggi. Oleh karena itu, hipotesis yang akan dikembangkan adalah sebagai berikut:

$\mathrm{H}_{2}$ : Komitem profesi berpengaruh terhadap perilaku auditor dalam menghadapi konflik audit.

\section{Pengaruh Budaya Organisasi terhadap Perilaku Auditor dalam Menghadapi Konflik Audit}

Menurut Dessler (1995) dalam Trisnaningsih (2007), budaya organisasi merupakan variabel penting bagi seorang pemimpin, karena budaya organisasi mencerminkan nilai-nilai yang diakui dan menjadi pedoman bagi pelaku sebagai anggota organisasi. Flamholtz dan Narasimhan (2005) dikutip dalam Trinaningsih (2007) menyatakan bahwa beberapa elemen budaya organisasi mempunyai pengaruh yang berbeda pada kinerja keuangan perusahaan.

Penelitian Trinaningsih (2007) dan Wulansari (2012) yang menyatakan bahwa budaya organisasi berpengaruh signifikan terhadap kinerja auditor tidak terbukti. Oleh karena itu, hipotesis yang akan dikembangkan adalah sebagai berikut: 
H3: Budaya organisasi berpengaruh terhadap perilaku auditor dalam menghadapi konflik audit

\section{Pengaruh Kepuasan Kerja terhadap Perilaku Auditor dalam Menghadapi Konflik Audit.}

Rasa puas seseorang dapat terlihat pada hasil akhir pekerjaannya. Begitu juga dengan auditor, ketika terdapat temuan yang muncul dan temuan tersebut dapat menjadi faktor pembangun perusahaan yang diaudit maka terdapat kepuasan atas pekerjaannya pada diri auditor. Namun kepuasan kerja terlihat bukan hanya dari hasil akhir saja, banyak peneliti yang sudah dilakukan menyatakan bahwa kepuasan kerja dipengaruhi oleh beberapa faktor. Diantaranya adalah kedudukan yang dimiliki dan pendidikan terakhir. Bila karyawan yang memiliki kedudukan yang lebih tinggi merasa lebih puas karena mereka memiliki otonomi yang lebih besar, pekerjaannya lebih bervariasi dan memiliki kebebasan dalam melakukan penilaian (Ostoff, 1992) dalam (Abdulloh, 2006).

Penelitiannya Prastiwi, (2011) juga telah membuktikan adanya pengaruh kepuasan kerja terhadap perilaku auditor dalam menghadapi konflik audit. Sehingga hipotesis yang akan dikembangkan adalah sebagai berikut:

H4: Kepuasan kerja berpengaruh terhadap perilaku auditor dalam menghadapi konflik audit.

\section{Pengaruh Sistem Kompensasi terhadap Perilaku Auditor dalam Menghadapi Konflik Audit.}

Hal ini terjadi ketika perusahaan memberikan jumlah kompensasi yang tidak sesuai kepada karyawannya. Kompensasi yang diterima oleh karyawan seharusnya sepadan dengan apa yang telah dikerjakan dan apa kedudukan karyawan tersebut dalam suatu perusahaan. Jika kompensasi yang diberikan tepat, maka pegawai akan memperoleh kepuasan kerja dan termotivasi untuk melakukan pekerjaannya semaksimal mungkin.

Sukarman, et al. (2008) dalam Prastiwi (2011) meneliti tentang insentif 
(kompensasi) dimana gaji yang memberikan rasa puas adalah gaji yang mampu mencukupi kebutuhan hidup sehingga menimbulkan rasa nyaman bagi para karyawann. Hasil penelitian tersebut dapat disimpulkan bahwa besaran kompensasi berpengaruh terhadap kinerja seorang karyawan dalam bekerja, dan besaran kompensasi tergantung pada tingkat pendidikan (Sarjana D3), kemampuan bekerja dan beban kerja. Oleh karena itu, hipotesis yang akan dikembangkan adalah sebagai berikut:

H5: Sistem kompensasi berpengaruh terhadap perilaku auditor dalam menghadapi konflik audit.

\section{Pengaruh Sikap Independensi terhadap Perilaku Auditor dalam Menghadapi Konflik Audit.}

Auditor ditempatkan dalam situasi konflik ketika menghadapi klien. Dalam laporan hasil audit, seorang auditor harus memberikan pendapatnya tentang temuan yang ditemukan. Namun di pihak lain pihak professional itu luntur karena pekerjaannya sebagai auditor harus mematuhi peraturan yang berada di kantor tersebut. Banyak faktor yang menentukan baik dan buruknya kualitas seorang audior dalam menghadapi konflik audit. Situasi tersebut akan terlihat mana auditor yang mempunyai kualitas yang baik dan yang buruk.

Independensi adalah sikap seorang auditor yang tidak memihak kepada siapapun dan dalam kondisi apapun. Jika seorang auditor memberikan keterangan yang tidak sama dengan hasil temuannya maka dapat dikatakan bahwa auditor tersebut memiliki intergitas yang rendah. Auditor dapat dikataka bagus dan akan dipertahankan dalam perserikatannya jika tingkat independensinya tinggi. Sehingga hipotesis yang akan dikembangkan adalah sebagai berikut:

H6 : Sikap independensi berpengaruh terhadap perilaku auditor dalam menghadapi konflik audit. 


\section{Model Penelitian}

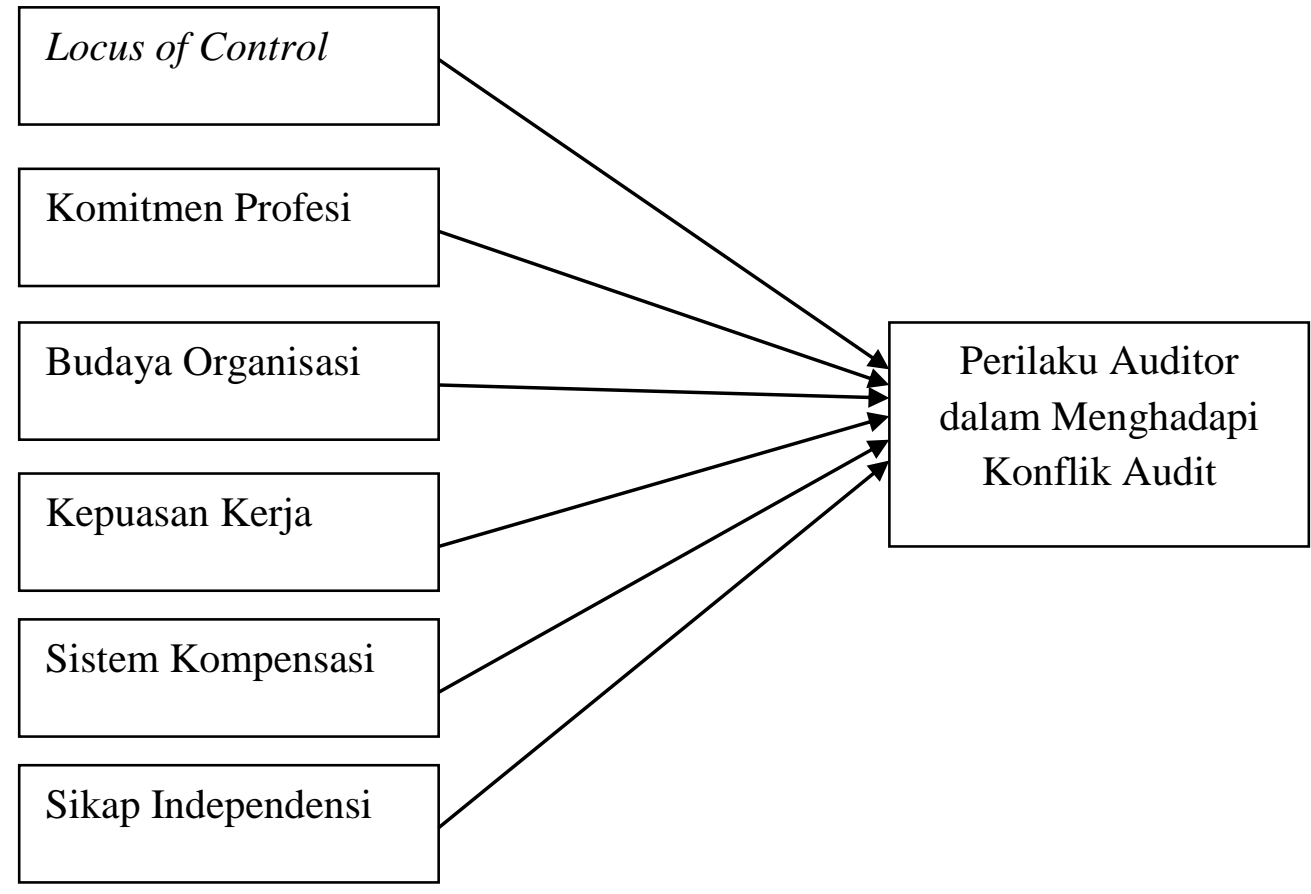

Gambar 1

Model Penelitian

\section{METODA PENELITIAN}

\section{Populasi dan Sampel}

Populasi dalam penelitian ini adalah Kantor Akuntan Publik (KAP) yang berada di Yogyakarta dan Surakarta. Penelitian ini mengambil sampel pada auditor yang bekerja di KAP yang berada di wilayah Yogyakarta dan Surakarta yaitu auditor minimal telah bekerja selama 2 tahun.

Jenis data yang digunakan dalam penelitian ini adalah data primer yang diperoleh dari daftar pertanyaan yang disusun secara tersetruktur dan sistematis guna memperoleh informasi dari auditor yang bekerja di Kantor Akuntan Publik di wilayah Yogyakarta dan Surakarta sesuai dengan tujuan peneliti.

\section{Definisi Operasional Variabel}

Variabel bebas terdiri dari locus of control ( $\left.\mathrm{X}_{1}\right)$, komitmen profesi $\left(\mathrm{X}_{2}\right)$, 
budaya organisasi $\left(\mathrm{X}_{3}\right)$, kepuasan kerja $\left(\mathrm{X}_{4}\right)$, sistem kompensasi (X5), dan sikap independensi (X6). Variabel-variabel tersebut diukur dengan skala Likert yang memungkinkan penulis untuk memberikan skor pada tiap jawaban responden. Metoda pengkuran skor yang digunakan dalam penelitian ini adalah 5 poin untuk setiap pertanyaan positif dimana semakin mengarah ke poin 1 menunjukkan perilaku auditor buruk dan jika mengarah ke poin 5 menggambarkan bahwa perilaku auditor bagus ketika menghadapi konflik audit.

\section{Locus of Control}

Pevin dalam Ayudiati (2010) dalam Waris (2012) menyatakan bahwa locus of control adalah istilah dalam psikologi yang mengacu kepada keyakinan seseorang tentang apa yang menyebabkan hasil yang baik atau buruk dalam hidupnya.

\section{Komitmen Profesi}

Komitmen profesi menurut Aranya dan Ferris (184: 2) dalam Prastiwi (2011) adalah suatu kepercayaan dan penerimaan pada tujuan dan nilai dalam suatu organisasi dan/atau profesi, kemampuan untuk melakukan usaha yang membutuhkan bagi organisasi dan/atau profesi.

\section{Budaya Organisasi}

Budaya organisasi didefinisikan sebagai nilai-nilai dominan yang disebarluaskan dalam perusahaan dan diacu sebagai filosofi kinerja karyawan.

\section{Kepuasan Kerja}

Kepuasan kerja yang dimaksud dalam penelitian ini adalah tingkat kepuasan kerja individual serang auditor yang bekerja pada Kantor Akuntan Publik Yogyakarta dan Surakarta.

\section{Sistem Kompensasi}

Sistem kompensasi yang diberikan mungkin akan mempengaruhi kinerja auditor intern dalam melaksanakan fungsinya dalam perusahaan Rahayu (2004) 
dikutip dalam Prastiwi (2011). Auditor intern akan berusaha memenuhi tuntutan manajemen secara keseluruhan meskipun bertentangan dengan prosedur yang benar dan melanggar kode etik yang telah diterapkan.

\section{Sikap Independensi}

Menurut Mulyadi (2002: 26), independensi adalah sikap mental yang bebas dari pengaruh, tidak dikendalikan oleh pihak lain, tidak tergantung pada orang lain. Independensi juga berarti adanya kejujuran dalam diri auditor dalam mempertimbangkan fakta dan adanya pertimbangan yang objektif tidak memihak dalam diri auditor dalam merumuskan dan menyatakan pendapatnya. Menurut Robbins dan Jugde (2008: 92) perilaku merupakan salah satu komponen sikap. Sikap (attitude) adalah pernyataan evaluatif, baik yang menggunakan maupun yang tidak menyenangkan, terhadap objek, individu, atau peristiwa.

\section{ALAT ANALISIS DATA}

\section{Uji Kualitas Data}

Uji validitas digunakan untuk mengukur sah atau valid tidaknya suatu kuesioner. Suatu kuesioner dikatakan valid jika pertanyaan pada kuesioner tersebut mampu mengungkapkan sesuatu yang diukur oleh kuesioner (Ghozali, 2006: 49). Sedangkan, reliabilitas adalah alat untuk mengukur suatu instrumen penelitian (kuesioner) yang merupakan indikator dari variabel atau konstruk (Ghozali, 2006: 45).

\section{Uji Asumsi Klasik}

\section{Uji Normalitas Data}

Uji normalitas data bertujuan untuk menguji ada atau tidaknya variabel pengganggu dalam model penelitian. Uji normalitas data ini akan diuji menggunakan Kolmogorov Smirnov. Pedoman pengambilan keputusannya yaitu jika nilai signifikansi $<0,05$ maka data berdistribusi tidak normal, namun jika nilai signifikansi > 0,05 maka data berdistribusi normal (Kurniawati, 2006: 18). 


\section{Uji Autokorelasi}

Uji autokorelasi bertujuan menguji dalam model regresi ada korelasi antara kesalahan pengganggu pada perioda $t$ dengan kesalahan pengganggu pada perioda t-1 (sebelumnya). Ada tidaknya autokorelasi dideteksi menggunakan Durbin Waston test dengan pengambilan keputusan jika nilai $\mathrm{du}<\mathrm{d}<4$-du maka tidak terjadi autokorelasi (Ghozali, 2006: 100).

\section{Uji Multikolinearitas}

Multikolinearitas adalah situasi adanya korelasi antara variabel-variabel independen dalam model regresi. Pengujian multikolinearitas dalam penelitian ini menggunakan variance inflation factor (VIF) dengan kriteria jika nilai tolerance $\leq$ 0,10 atau sama dengan nilai $\mathrm{VIF} \geq 10$, maka terdapat multikolinearitas antara variabel independen (Ghozali, 2006: 96).

\section{Uji Heteroskedastisitas}

Uji heteroskedastisitas bertujuan menguji dalam model regresi terjadi ketidaksamaan variance dari residual satu pengamatan ke pengamatan yang lain (Ghozali, 2006 : 125). Deteksi ada atau tidaknya heterokedastisitas digunakan uji Glejser dengan kriteria apabila koefisien parameter nilai signifikan lebih dari alpha $5 \%$ maka tidak terdapat heteroskedastisitas.

\section{Uji Hipotesis}

Alat pengujian yang digunakan dalam penelitian ini adalah analisis regresi berganda, untuk itu diformulasikan model regresi berganda sebagai berikut:

$$
Y=\alpha+\beta_{1} X_{1}+\beta_{2} X_{2}+\beta_{3} X_{3}+\beta_{4} X_{4}+\beta_{5} X_{5}+\beta_{6} X_{6}+e
$$

Keterangan:

$\mathrm{Y}$

A

$\beta_{1}, \beta_{2}, \beta_{3}, \beta_{4}, \beta_{5}, \beta_{6}$
: Perilaku auditor

: Konstanta

: Koefisien Regresi 
$\mathrm{X}_{1}$

$\mathrm{X}_{2}$

$\mathrm{X}_{3}$

$\mathrm{X}_{4}$

$\mathrm{X}_{5}$

$\mathrm{X}_{6}$

e
: Locus of control

: Komitmen profesi

:Budaya Organisasi

: Kepuasan kerja

: Sistem kompensasi

: Sikap Independensi

: Error

\section{Koefisien Determinasi}

Koefisien determinasi $\left(\mathrm{R}^{2}\right)$ mengukur seberapa jauh kemampuan model dalam menerangkan variasi variabel dependen. Nilai $\mathrm{R}^{2}$ yang mendekati satu maka variabel independen memberikan hampir semua informasi yang dibutuhkan untuk memprediksi variasi variabel dependen.

\section{Uji F}

Menurut Ghozali (2006: 88), uji statistik F pada dasarnya menunjukkan bahwa semua variabel independen atau bebas yang dimasukan dalam model di uji secara bersama-sama terhadap variabel dependen atau terkait. Nilai signifikansi $\mathrm{F}$ yang digunakan dalam penelitian ini yaitu dkurang dari $5 \%$.

\section{Uji t}

Uji statistik pada dasarnya menunjukkan pengaruh satu variabel penjelas dalam menerangkan variabel terkait (Ghozali, 2006 : 88). Hipotesis 1, 2, 3, 4, 5, 6 dalam penelitian ini didukung apabila nilai signifikansi $\mathrm{t}<5 \%$. Artinya jika nilai signifikansi lebih besar dari level of significance $(\operatorname{sig}>\alpha)$ berarti tidak terdapat pengaruh yang nyata antara variabel independen terhadap variabel dependen. 


\section{HASIL PENELITIAN DAN PEMBAHASAN}

\section{Pengujian Kualitas Data}

Hasil dari uji validitas menunjukkan bahwa seluruh item pertanyaan dalam instrumen mempunyai nilai signifikansi rhitung < rtabel maka dapat disimpulkan bahwa semua pertanyaan dalam instrumen valid. Kecuali pada variabel locus of control pada pertanyaan ke 4, 5, 6, 7, 9, 11, 12, 14, 15. Kepuasan kerja pada pertanyaan 6 , independensi auditor pada pertanyaan ke 5 dan 9 , serta perilaku audit pada pertanyaan ke 9 dan 10 lebih dari nilai rhitung < rtabel sehingga peneliti penghapus butiran pertanyaan tersebut.

Menurut Ghozali (2006: 45) reabilitas adalah alat untuk mengukur suatu instrumen penelitian (kuesioner) yang merupakan indikator dari variabel atau konstruk.

\section{Tabel 1}

Hasil Uji Reliabilitas

\begin{tabular}{|c|c|c|}
\hline Variabel & Cronbach Alpha & Keterangan \\
\hline Locus of Control & 0,901 & Reliabel \\
\hline Komitmen Profesi & 0,887 & Reliabel \\
\hline Budaya Organisasi & 0,899 & Reliabel \\
\hline Kepuasan Kerja & 0,780 & Reliabel \\
\hline Sistem Kompensasi & 0,850 & Reliabel \\
\hline Sikap Independensi & 0,839 & Reliabel \\
\hline Perilaku Auditor & 0,879 & Reliabel \\
\hline
\end{tabular}

Sumber: Data primer, diolah (2013)

Berdasar uji reliabilitas diketahui bahwa cronbach alpha $>0,60$. Sehingga dapat diketahui bahwa semua variabel instrumen penelitian dinyatakan reliabel.

\section{Uji Asumsi Klasik}

\section{Uji Normalitas Data}

Berdasar pada tabel 2 mengenai hasil uji normalitas data, menunjukkan bahwa nilai signifikansi > 0,05 (alpha). Dengan demikian, dapt diketahui bahwa data tersebut berdistribusi normal. 
Tabel 2

Hasil Uji Normalitas Data

\begin{tabular}{|l|c|}
\hline & Ustandardized Residual \\
\hline Kolmogorov-Smirnov $Z$ & 0,475 \\
\hline Asymp. Sig. (2-tailed) & 0,978 \\
\hline
\end{tabular}

Sumber: Data primer, diolah (2013)

\section{Uji Autokorelasi}

Berdasar hasil uji autokorelasi menunjukkan nilai Durbin Watson sebesar 2,057 lebih besar dari batas atas (du) 1,870 dan kurang dari 4-1,870 (4-du). Oleh karena itu, tidak terjadi autokorelasi dalam model penelitian.

\section{Tabel 3}

\section{Hasil Uji Autokorelasi}

\begin{tabular}{|c|}
\hline Durbin Watson \\
\hline 2,057 \\
Sumber: Data primer, diolah (2013)
\end{tabular}

\section{Uji Multikolinieritas}

Berdasar tabel uji multikolinearitas dapat dilihat pehitungan nilai tolerance menunjukkan tidak ada variabel yang memiliki nilai tolerance kurang dari 0,10 berarti tidak ada korelasi antar variabel. Dapat disimpulkan bahwa tidak multikolinearitas.

Tabel 4

Hasil Uji Multikolinearitas

\begin{tabular}{|l|l|l|l|}
\hline Variabel & Tolerance & VIF & Keterangan \\
\hline Locus of Control & 0,846 & 1,181 & Tidak Multikolinearitas \\
\hline Komitmen Profesi & 0,393 & 2,542 & Tidak Multikolinearitas \\
\hline Budaya Organisasi & 0,448 & 2,233 & Tidak Multikolinearitas \\
\hline Kepuasan Kerja & 0,299 & 3,340 & Tidak Multikolinearitas \\
\hline Sistem Kompensasi & 0,395 & 2,529 & Tidak Multikolinearitas \\
\hline Sikap Independensi & 0,600 & 1,666 & Tidak Multikolinearitas \\
\hline
\end{tabular}

Sumber: Data primer, diolah (2013)

\section{Uji Heteroskedastisitas}

Berdasar hasil uji heteroskedastisitas setiap variabel independen menujukkan 
nilai signifikansi lebih dari alpha (5\%). Dengan demikian, dapat diketahui bahwa dalam model regresi tidak terdapat heteroskedastisitas.

Tabel 5

Hasil Uji Heteroskedastisitas

\begin{tabular}{|l|c|c|l|}
\hline Variabel & Nilai Sig & Alpha & \multicolumn{1}{|c|}{ Keterangan } \\
\hline Locus of Control & 0,154 & 0,05 & Tidak terdapat Heteroskedastisitas \\
\hline Komitmen Profesi & 0,816 & 0,05 & Tidak terdapat Heteroskedastisitas \\
\hline Budaya Organisasi & 0,971 & 0,05 & Tidak terdapat Heteroskedastisitas \\
\hline Kepuasan Kerja & 0,061 & 0,05 & Tidak terdapat Heteroskedastisitas \\
\hline Sistem Kompensasi & 0,092 & 0,05 & Tidak terdapat Heteroskedastisitas \\
\hline Sikap Independensi & 0,623 & 0,05 & Tidak terdapat Heteroskedastisitas \\
\hline
\end{tabular}

Sumber: Data primer, diolah (2013)

\section{Uji Hipotesis}

\section{Koefisien Determinasi}

Berdasarkan hasil uji koefisien determinasi $\left(\mathrm{R}^{2}\right)$ besarnya adjusted $\mathrm{R}^{2}$ adalah 0,636 hal ini berarti bahwa 63,6\% variabel perilaku auditor dalam menghadapi konflik audit dapat dijelaskan oleh variabel locus of control, komitmen profesi, budaya organisasi, kepuasan kerja, sistem kompensasi, sikap independensi. Sedangkan sisanya 36,4\% dijelaskan oleh sebab-sebab lain diluar model.

Tabel 6

Hasil uji Determinasi

\begin{tabular}{|c|c|}
\hline Model & Adjusted $R$ Square \\
\hline 1 & 0,636 \\
\hline
\end{tabular}

Sumber: data primer, diolah (2013)

\section{Uji Simutan (Uji statistik F)}

Berdasar hasil uji $\mathrm{F}$ pada tabel dapat dilihat nilai $\mathrm{F}$ hitung sebesar 11,489 dengan probabilitas 0,000 yang berarti jika di uji secara bersama-sama locus of control, komitmen profesi, budaya organisasi, kepuasan kerja, sistem kompensasi, sikap independensi berpengaruh terhadap perilaku auditor dalam menghadapi konflik audit. 
Tabel 7

Hasil uji F

\begin{tabular}{|c|c|}
\hline F Hitung & Signifikansi \\
\hline 11,489 & 0,000 \\
\hline
\end{tabular}

\section{Uji Parameter Individual (uji t)}

Tabel 7

Hasil uji F

\begin{tabular}{|l|c|c|}
\hline \multicolumn{1}{|c|}{ Variabel } & Signifikansi & Keterangan \\
\hline Locus of control & 0,000 & $\mathrm{H}_{1}$ diterima \\
\hline Komitmen Profesi & 0,002 & $\mathrm{H}_{2}$ diterima \\
\hline Budaya Organisasi & 0,002 & $\mathrm{H}_{3}$ diterima \\
\hline Kepuasan Kerja & 0,018 & $\mathrm{H}_{4}$ diterima \\
\hline Sistem Kompensasi & 0,014 & $\mathrm{H}_{5}$ diterima \\
\hline Sikap Independensi & 0,013 & $\mathrm{H}$ diterima \\
\hline
\end{tabular}

Sumber: data primer (2013)

Berdasarkan tabel 4 dapat dilihat bahwa dari hipotesis 1, 2, 3, 4, 5 dan 6 dalam penelitian ini signifikansi $\mathrm{t}<5 \%$.

1. Hasil uji statistik terhadap hipotesis pertama menunjukkan nilai probabilitas kurang dari 5\% yakni 0,001. Dengan demikian $\mathrm{H}_{1}$ diterima, sehingga locus of control berpengaruh terhadap perilaku auditor dalam menghadapi konflik audit. Hal ini sejalan dengan penelitian yang telah dilakukan oleh Kurnia (2002) bahwa locus of control berpengaruh positif terhadap perilaku auditor. Dengan demikian dapat diartikan bahwa sebagian besar auditor memiliki perilaku internal locus of control mempunyai sifat yang lebih bertanggung jawab dan segala sesuatu yang baik dan buruk tergantung pada diri kita sendiri. Sehingga cenderung dapat mengendalikan diri pada saat situasi konflik audit dan menerima berbagai tekanan dari klien.

2. Hasil uji statistik terhadap hipotesis kedua menunjukkan nilai probabilitas kurang dari 5\% yakni 0,001. Dengan demikian $\mathrm{H}_{2}$ diterima sehingga komitmen profesi berpengaruh terhadap perilaku auditor dalam menghadapi konflik audit. Seorang auditor dapat dikatakan mempunyai tingkat loyalitas tinggi ketika 
melaksanakan aturan dalam komitmen profesinya, semakin auditor tersebut mematuhi aturan yang ada, maka dapat dikatakan komitmen profesinya tinggi. Hal ini sejalan dengan penelitian yang telah dilakukan oleh Suhakim dan Arisudhana (2012) membuktikan komitmen profesi berpengaruh signifikan terhadap perilaku auditor dalam situasi konflik.

3. Hasil uji statistik terhadap hipotesis ketiga menunjukkan nilai probabilitas kurang dari 5\% yakni 0,011. Dengan demikian $\mathrm{H}_{3}$ diterima sehingga budaya organisasi berpengaruh terhadap perilaku auditor dalam menghadapi konflik audit. Emons (1986) dalam Widyarini (2009) mengungkapkan bahwa individu merasa tidak nyaman dalam suatu lingkungan akan mengalami ketidak berdayaan, kekhawatiran. Sebaliknya kalau ia merasa nyaman dengan lingkungannya ia akan memperlihatkan sifat positif dan memilih tinggal lebih lama dalam lingkungan tersebut. Budaya organisasi dalam penelitian ini adalah KAP, auditor merasa nyaman dalam lingkungan dan pekerjaannya, maka perilaku auditor akan semakin baik.

4. Hasil uji statistik terhadap hipotesis keempat menunjukkan nilai probabilitas kurang dari 5\% yakni 0,015. Dengan demikian $\mathrm{H}_{4}$ diterima sehingga kepuasan kerja berpengaruh terhadap perilaku auditor dalam menghadapi konflik audit. Hal ini sejalan dengan penelitian yang telah dilakukan oleh Prastiwi (2011) bahwa kepuasan kerja berpengaruh terhadap perilaku auditor dalam menghadapi konflik audit. Dengan demikian dapat diartikan bahwa adanya kepuasan yang dirasakan oleh auditor mengakibatkan perilaku auditor lebih tekun dalam bekerja.

5. Hasil uji statistik terhadap hipotesis kelima menunjukkan nilai probabilitas kurang dari 5\% yakni 0,022. Dengan demikian $\mathrm{H}_{5}$ diterima sehingga sistem kompensasi berpengaruh terhadap perilaku auditor dalam menghadapi konflik audit. Mareta (2011) mengemukakan kompensasi merupakan support yang sangat mendukung dalam rangka memotivasi pelaksanaan pekerjaan. Dengan adanya kompensasi yang memuaskan, maka akan mendorong kinerja bagi para 
auditor dan dan akan juga meningkatakan independensi auditor.

6. Hasil uji statistik terhadap hipotesis keenam menunjukkan nilai probabilitas kurang dari 5\% yakni 0,035. Dengan demikian H6 diterima sehingga sikap independensi berpengaruh terhadap perilaku auditor dalam menghadapi konflik audit. Independensi adalah sikap seorang auditor yang tidak memihak kepada siapapun dan dalam kondisi apapun. Kode Etik Akuntan Indonesia pasal 1 ayat 2 menyatakan bahwa setiap anggota harus mempertahankan integritas, objektivitas dan independensi dalam melaksanakan tugasnya. Seorang auditor yang mempertahankan integritas, akan bertindak jujur dan tegas dalam mempertimbangkan fakta, terlepas dari kepentingan pribadi. Auditor yang mempertahankan objektivitas, akan bertindak adil tanpa dipengaruhi tekanan dan permintaan pihak tertentu atau kepentingan pribadinya. Auditor yang menegakkan independensinya, tidak akan terpengaruh dan tidak dipengaruhi oleh berbagai kekuatan yang berasal dari luar diri auditor dalam mempertimbangkan fakta yang dijumpainya dalam pemeriksaan.

\section{SIMPULAN, KETERBATASAN, DAN SARAN}

Berdasar hasil pembahasan dan analisis data maka dapat ditarik simpulan dari penelitian ini bahwa variabel locus of control, komitmen profesi, budaya organisasi, kepuasan kerja, sistem kompensasi serta sikap independensi berpengaruh terhadap perilaku auditor dalam menghadapi konflik audit.

Penelitian ini juga memiliki keterbatasan yaitu, jumlah akuntan publik yang menjadi sampel dalam penelitian ini sangat terbatas, hal ini dikarenakan sangat terbatasnya akuntan publik yang ada di wilayah Yogyakarta dan Surakarta yang mau menerima dan yang mengisi kuesioner. Selain itu, kesesuaian waktu antara peneliti dengan responden yang akan diteliti kurang tepat sehingga memakan waktu cukup lama.

Berdasar keterbatasan yang ada, maka saran untuk penelitian selanjutnya adalah dengan memperluas ruang lingkup ke wilayah lainnya, yaitu wilayah yang 
mempunyai banyak akuntan publik. Selain itu, peneliti hendaknya memperhatikan pemilihan kesesuaian waktu yang tepat dalam penelitian khususnya responden yang akan diteliti. Oleh karena itu, sebaiknya sebelum terjun ke lapangan disarankan untuk survei terlebih dahulu.

\section{DAFTAR PUSTAKA}

Abdulloh. 2006. "Pengaruh Budaya Organisasi, Locus of control dan Kepuasan Kerja terhadap Kinerja Karyawan pada Kantor Pelayanan Pajak Semarang Barat”. Tesis. Semarang: Universitas Diponegoro.

Andini, Rita. 2006. "Analisis Pengaruh Kepuasan Gaji, Kepuasan Kerja, Komitmen Organisasional terhadap Turnover Intention (Studi Kasus pada Rumah Sakit Roemani Muhammadiyah Semarang). Tesis. Universitas Diponegoro Semarang.

Atmini, Tuban Dirjah dan Herawati Sari. 2010. "Perbedaan Perilaku Auditor dalam Situasi Konflik Audit Dilihat dari Segi Gender: Peran Locus of Control, Komitmen Profesi, dan Kesadaran Etis". Fakultas Ekonomi Universitas Brawijaya Malang. Jurnal Aplikasi Manajemen, Vol 8, No.12, Mei. Malang.

Araminta, Safrinda Rahma. 2011. "Emosional Spiritual Quotient dan Locus of Control sebagai Anteseden Hubungan Kinerja Pegawai dan Penerimaan Perilaku Disfungsional Audit (Studi pada Inspektorat Provinsi Jawa Tengah). Skripsi. Universitas Diponegoro.

Dwintasari, MSY. Fadhilah. 2008. "Pengaruh Locus of Control, Komitmen Profesi dan Ketidakpastian Lingkungan terhadap Perilaku Auditor dalam Situasi Konflik Audit dengan Kesadaran Etis sebagai Variabel Moderating". Skripsi. Surakarta: Universitas Muhammadiyah Surakarta.

Gozali, Imam. 2006. Aplikasi Analisis Multivariate dengan Pogram SPSS. Semarang: Universitas Diponegoro.

Handoko. Hani T. 2010. Manajemen Personalia dan Sumberdaya Manusia. Edisi 2. Yogyakarta: BPFE UGM. 
Herawati, Fahalina. 2007. "Pengaruh Persepsi dan Kesadaran Etis terhadap Komitmen Profesi Akuntan Publik (Survei pada Kantor Akuntan Publik Wilayah Surakarta)”. Skripsi. Semarang: Universitas Negeri Semarang.

Hutami, Gartiria \& Chariri, Anis (2011) "Pengaruh Konflik Peran dan Ambiguritas Peran terhadap Komitmen Independensi Auditor Internal Pemerintah Daerah (Studi Empiris pada Inspektorat Kota Semarang): Tesis. Universitas Diponegoro.

Indriantoro, Nur dan Bambang Supomo. 1999. Metode Penelitian Bisnis untuk Akuntansi dan Manajemen. Yogyakarta: BPFE UGM.

Kasidi. 2007. "Faktor-Faktor yang Mempengaruhi Independensi Auditor (Persepsi Manajer Keuangan Perusahaan Manufaktur Jawa Tengah)”. Tesis. Universitas Diponegoro.

Kusumaningsih, Vera. 2012. "Pengaruh Motivasi Kerja terhadap Kepuasan Kerja dan Prestasi Kerja Auditor Eksternal Pemerintah (Studi Empiris pada Auditor di BPK Perwakilan Provinsi Daerah Istimewa Yogyakarta)". Skripsi. Yogyakarta: Universitas Ahmad Dahlan.

Kurnia. 2002. "Pengaruh Desain Organisasional dan Locus of control terhadap Perilaku Manipulatif dalam Penetapan Harga Transfer”. JAAI Vol. 6. No.1.

Kurniawati, Indah. 2006. Modul Pengolahan Data Elektronik. Yogyakarta: Universitas Ahmad Dahlan.

Mareta, Rena. 2011. "Pengaruh Tingkat Pendidikan, Pengalaman dan Kompensasi terhadap Kinerja Auditor pada Kantor Akuntan Publik Daerah Istimewa Yogyakarta”. Skripsi. Yogyakarta: Universitas Negeri Yogyakarta.

Martoyo, susilo. 2000. Manajemen Personalia dan Sumberdaya Manusia. Edisi 4. Yogyakarta: BPFE.

Mulyadi 2002. Auditing Edisi 6. Jakarta: Salemba Empat.

Pramana, Aji Ahmad. 2012. "Pengaruh Independensi Auditor, Gaya 
Kepemimpinan, Komitmen Organisasi dan Akuntabilitas terhadap Kinerja Auditor (Studi Empiris pada Auditor Pemerintah di BPK Jateng). Skripsi. Yogyakarta: Universitas Ahmad Dahlan.

Prastiwi, Indras Wahyu. 2011. "Pengaruh Locus of Control, Komitmen Profesi, Kepuasan Kerja, Sistem Kompensasi serta Sikap Independensi terhadap Perilaku Auditor dalam Menghadapi Konflik Audit". Skripsi. Yogyakarta: Universitas Ahmad Dahlan.

Trisnaningsih, Sri. 2007. "Independensi Auditor dan Komitmen Organisasi Sebagai Mediasi Pengaruh Pemahaman Good Governance, Gaya Kepemimpinan, dan Budaya Organisasi terhadap Kinerja Auditor”. Simposium Nasional Akuntansi X. Makassar (Juli).

Stephen P. Robbins-Timothy A. Judge. 2008. "Perilaku Organisasi". Jakarta: Salemba Empat.

Suhakim, Imam Ade dan Arisudhana Dicky. "Pengaruh Gender, Locus of control, Komitmen Profesi, dan Kesadaran Etis terhadap Perilaku Auditor dalam Situasi Konflik”. Jurnal Akuntansi dan Keuangan Vol.1 No.1 April 2012.

Waris, Abdul. 2012. "Pengaruh Gaya Kepemimpinan dan Locus of Control terhadap Kinerja (Studi Kasus pada Auditor yang Bekerja di BPKP Daerah Istimewa Yogyakarta). Skripsi. Yogyakarta: Universitas Ahmad Dahlan.

Widyarini, Dyah. 2009. Pengaruh Budaya Organisasi terhadap Kepuasan Kerja dan Kreatifitas Auditor/Pegawai Inspektorat Kabupaten Banjarnegara. Tesis. Semarang: Universitas Diponegoro.

Wulansari, Indriani. 2012. Pengaruh Independensi Auditor, Komitmen Organisasi, Gaya Kepemimpinan, Budaya Organisasi, dan Pemahaman Good Governance terhadap Kinerja Auditor. Skripsi. Yogyakarta: Universitas Ahmad Dahlan. 